\title{
ANALISIS PEMUNGUTAN PAJAK RESTORAN DAN KONTRIBUSINYA TERHADAP PENDAPATAN ASLI DAERAH KABUPATEN MINAHASA.
}

\author{
Wensy F. I. Rompas \\ Fakultas Ekonomi dan Bisnis Program Magister Ilmu Ekonomi \\ Universitas Sam Ratulangi \\ email : wensyrompas@yahoo.co.id
}

\begin{abstract}
ABSTRAK
Pajak Restoran adalah pajak atas pelayanan restoran. Pemugutan Pajak Restoran di Indonesia saat ini didasarkan pada Undang-Undang Nomor 34 Tahun 2000 yang merupakan peubahan atas Undang-Undang Nomor 18 Tahun 1997 tentang Pajak Daerah dan Retribusi Daerah dan Peraturan Pemerintah No. 65 Tahun 2001 tentang Pajak Daerah. Penelitian ini bertujuan untuk mengetahui prosedur pelaksanaan pemungutan pajak restoran di Kabupaten Minahasa dan mengetahui kontribusi pajak restoran terhadap pendapatan Asli Daerah di Kabupaten Minahasa. Data yang digunakan dalam penelitian ini adalah data kuantitatif berupa data pajak Restoran di Dinas Pengelola Keuangan, Aset dan Pendapatan Daerah Kabupaten Minahasa. Metode analisis yang digunakan adalah analisis deskripsi. yaitu untuk menggambarkan menganalisis hasil dari penelitian yang telah dilakukan. Penelitian menunjukan bahwa prosedur pelaksanaan pemungutan pajak telah berjalan baik dan mudah untuk dipahami serta bukti potong pembayaran dapat diberikan kepada wajib pajak. Tetapi setiap terjadi perubahan peraturan, petugas pemungut pajak dalam hal ini pemerintah daerah terlambat dalam mensosialisaikannya kepada wajib pajak. Sehingga masih ada wajib pajak belum membayarkan pajaknya. Kontribusi pajak restoran terhadap pendapatan asli daerah dapat dikatakan cukup baik walaupun setiap tahunnya mengalami penurunan. Walaupun demikian secara keseluruhan sudah mencapai target yang sudah ditetapkan.
\end{abstract}

Kata kunci : Pemungutan Pajak Restoran dan Pendapatan Asli Daerah.

\begin{abstract}
ABSTRAK
Restaurant Tax is a tax on restaurant services. Restaurant Tax Collection in Indonesia at this time is based on Law No. 34 of 2000 which is the amendment to Law No. 18 Year 1997 on Regional Taxes and Levies and Government Regulation No. 65 of 2001 on Local Taxes. This study aims to determine the procedure for collection of the tax in Minahasa restaurant and know the tax contribution to earnings original local restaurant in Minahasa. The data used in this research is quantitative data in the form of tax data in the Office business Restaurants Finance, Asset and Revenue Minahasa District. The analytical method used is descriptive analysis. namely to describe analyze the results of the research that has been done. Research shows that the procedure of implementation of tax collection has been going well and easy to understand as well as pieces of evidence of payment can be given to the taxpayer. But any changes in regulations, tax collector officer in this case the local government late in mensosialisaikannya to the taxpayer. So there is still a taxpayer has not paid the tax. Restaurant tax contributions to local revenues can be quite good although each year has decreased. Nevertheless, on the whole has reached the targets set.
\end{abstract}

Keywords: Tax Collection Restaurant and Local Revenue. 


\section{PENDAHULUAN}

\section{Latar Belakang}

Salah satu pajak daerah yang potensinya semakin berkembang seiring dengan semakin diperhatikannya komponen sektor jasa dan pariwisata dalam kebijakan pembangunan sehingga dapat menunjang berkembangnya bisnis adalah pajak restoran. Semula menurut Undang-Undang Nomor 18 Tahun 1997 pajak atas hotel disamakan dengan pajak restoran dengan nama pajak hotel dan restoran. Perubahan undang-undang tentang pajak daerah dan retribusi, dikeluarkannya Undang-Undang Nomor 34 Tahun 2000 membuat pajak hotel dan pajak restoran dipisahkan menjadi jenis pajak yang berdiri sendiri. Ini mengindikasikan besarnya potensi akan keberadaan pajak restoran dalam pembangunan suatu daerah.

Berdasarkan Undang-Undang No. 28 Tahun 2009 tentang Pajak Daerah dan Retribusi Daerah, yang merupakan penyempurnaan Undang-Undang No. 34 Tahun 2004 tentang Pajak Daerah dan Retribusi Daerah, dijelaskan bahwa pajak restoran adalah pajak atas pelayanan yang disediakan oleh restoran.

Pajak daerah yang digolongkan sebagai pajak kabupaten/kota yaitu Pajak Hotel; Pajak Restoran; Pajak Hiburan; Pajak Reklame; Pajak Parkir; Pajak Pengambilan Bahan Galian Golongan C; Pajak Sarang Burung Walet; Pajak Bumi dan Bangunan Perdesaan dan Perkotaan; Bea Perolehan Hak atas Tanah dan Bangunan dan Pajak Penerangan Jalan.

Pajak Restoran adalah pajak atas pelayanan restoran. Pemugutan Pajak Restoran di Indonesia saat ini didasarkan pada Undang-Undang Nomor 34 Tahun 2000 yang merupakan peubahan atas Undang-Undang Nomor 18 Tahun 1997 tentang Pajak Daerah dan Retribusi Daerah dan Peraturan Pemerintah No. 65 Tahun 2001 tentang Pajak Daerah.

Pengenaan Pajak Restoran tidak mutlak ada pada seluruh daerah kabupaten atau kota di Indonesia. Hal ini berkaitan dengan kewenagan yang diberikan kepada pemerintah kabupaten/kota untuk mengenakan atau tidak mengenakan suatu jenis pajak kabupaten/kota. Pemerintah daerah harus terlebih dahulu menerbitkan peraturan daerah tentang Pajak Restoran yang menjadi landasan hukum operasional dalam teknis pelaksanaan pengenaan dan pemunggutan Pajak Restoran di daerah kabupaten atau kota yang bersangkutan untuk dapat dipunggut pada suatu daerah kabupaten kota.

Kabupaten Minahasa merupakan salah satu kabupaten di Propinsi Daerah Sulawesi Utara, memiliki potensi kuliner yang beraneka ragam yang cukup potensial untuk dikembangkan selain sector pariwisata dan beberapa sektor terkait, misal sektor perdagangan dan penyediaan jasa, merupakan salah satu sumber pendapatan daerah yang bisa digali dan terus dikembangkan. Adanya potensi kuliner dan budaya yang merupakan salah satu andalan Kabupaten Minahasa ini sudah selayaknya memberikan kontribusi terhadap beberapa penerimaan pajak yang ada.Kontribusi penerimaan daerah tersebut dapat berasal dari pajak maupun retribusi yang dipungut atas dasar pemberian jasa dan pelayanan oleh tempat kuliner di Kabupaten Minahasa.

Upaya peningkatan oleh Dinas Pendapatan Asli Daerah khususnya pajak restoran harus dilakukan secara terintegrasi dan terkordinasi dari keseluruhan sistem penerimaan daerah. Harus ditemukan sumber penyebab masalah pokok dari kecilnya penerimaan pajak restoran yang merupakan langkah pertama yang harus dilakukan untuk memperoleh alternatif pemecahan masalah Agar upaya tersebut efektif, sehingga dapat dilihat sejauh mana pajak Restoran yang merupakan salah satu komponen Pajak Daerah Kab. Minahasa yang memberikan sumbangannya bagi Pendapatan Asli Daerah Kab. Minahasa.

\section{Rumusan Masalah}

Permasalahan yang dihadapi oleh pemerintah kab.Minahasa adalah adanya kesalahan terhadap pemungutan pajak restoran serta kontribusinya terhadap pendapatan asli daerah. Padahal, terdapat potensi yang cukup besar untuk meningkatkan penerimaan pajak restoran.

Beberapa pertanyaan dalam penelitian ini sebagai berikut: 
a. Bagaimana pemungutan pajak restoran di Kabupaten Minahasa ?

b. Berapa besar kontribusi pajak restoran terhadap Pendapatan Asli Daerah Kabupaten Minahasa

\section{Tujuan Penelitian}

Tujuan penelitian ini, yaitu antara lain :

a. Mengetahui pelaksanaan pemungutan pajak restoran di Kabupaten Minahasa.

b. Mengetahui kontribusi pajak restoran terhadap pendapatan Asli Daerah di Kabupaten Minahasa.

\section{TINJAUAN PUSTAKA}

\section{Pajak Daerah}

Mardiasmo (2009:12), menjelaskan bahwa Pajak Daerah adalah iuran wajib oleh orang pribadi atau badan kepada daerah tanpa imbalan langsung yang seimbang, yang dapat dipaksakan berdasarkan peraturan perundang-undangan yang berlaku, yang digunakan untuk membiayai penyelenggaraan pemerintahan daerah dan pembangunan daerah.

Siahaan (2008:10), mengungkapkan bahwa Pajak Daerah adalah iuran wajib yang di lakukan oleh pribadi atau badan kepada daerah tanpa imbalan langsung yang seimbang, yang dapat dipaksakan berdasarkan peraturan perundang-undangan yang berlaku yang digunakan untuk membiayai penyelenggaraan pemerintahan dan pembangunan daerah.

Siahaan (2008:8), mengungkapkan bahwa ciri-ciri pajak daerah adalah sebagai berikut:

1. Pajak daerah merupakan setoran sebagian individu atau badan untuk kas Negara sesuai dengan ketentuan Undang-undang.

2. Sifat pemungutannya dapat dipaksakan dan tidak mendapat prestasi atau imbalan kembali secara langsung.

3. Penerimaan pajak oleh Negara dipakai untuk pengeluaran Negara dan melayani kepentingan masyarakat.

\section{Pajak Restoran}

Pajak Restoran adalah pajak atas pelayanan restoran. Pemungutan pajak restoran di Indonesia saat ini didasarkan pada Undang-Undang Nomor 34 Tahun 2000 yang merupakan perubahan atas UndangUndang Nomor 18 Tahun 1997 tentang Pajak Daerah dan Retribusi Daerah dan Peraturan Pemerintah Nomor 65 Tahun 2001 tentang Pajak Daerah. Semula menurut Undang-Undang Nomor 18 Tahun 1997 Pajak atas Hotel disamakan dengan Restoran dengan nama Pajak Hotel dan Restoran. Berdasarkan Undang-Undang Nomor 34 Tahun 2000 jenis pajak tersebut dipisahkan menjadi dua jenis pajak yang berdiri sendiri, yaitu Pajak Hotel dan Pajak Restoran.

Pengenaan Pajak Restoran tidak mutlak ada pada seluruh daerah kabupaten atau kota yang ada di Indonesia. Hal ini berkaitan dengan kewenangan yang diberikan kepada pemerintah kabupaten atau kota untuk mengenakan atau tidak mengenakan suatu jenis pajak kabupaten atau kota . Pemerintah daerah harus terlebih dahulu menerbitkan peraturan daerah tentang Pajak Restoran yang akan menjadi landasan hokum operasional dalam teknis pelaksanaan pengenaan dan pemungutan Pajak Restoran di daerah kabupaten atau kota yang bersangkutan, untuk dapat dipungut pada suatu daerah kabupaten atau kota Pemungutan pajak restoran terdapat beberapa terminologi yang perlu diketahui. Terminologi tersebut dapat dilihat berikut ini:

a. Restoran adalah tempat menyantap makanan dan atau minuman yang disediakan dengan dipungut bayaran, tidak termasuk usaha jasa boga dan katering.

b. Pengusaha restoran adalah orang pribadi atau badan dalam bentuk apa pun, yang dalam lingkungan perusahaan atau pekerjaannya melakukan usaha di bdang rumah makan. 
c. Pembayaran adalah jumlah yang diterima atau seharusnya diterima sebagai imbalan atas penyerahan barang atau pelayanan, sebagai pembayaran kepada pemilik rumah makan.

d. Bon penjualan (bill) adalah bukti pembayaran, yang sekaligus sebagai bukti pungutan pajak, yang dibuat oleh wajib pajak pada saat mengajukan pembayaran atas pembelian makanan dan atau minuman kepada subjek pajak.

\section{Objek Pajak Restoran dan Bukan Objek Pajak Restoran}

Objek Pajak Restoran adalah pelayanan yang disediakan restoran dengan pembayaran.Termasuk dalam objek Pajak Restoran adalah rumah makan, cafe, bar, dan sejenisnya.Pelayanan di restoran/rumah makan meliputi penjualan makanan dan atau minuman di restoran/rumah makan, termasuk penyediaan penjualan makanan/minuman yang diantar/dibawa pulang.

Pajak restoran tidak semua pelayanan yang diberikan oleh restoran/ rumah makan dikenakan pajak. Ada beberapa pengecualian yang tidak termasuk objek pajak, yaitu:

a. $\quad$ Pelayanan usaha jasa boga atau catering

b. Pelayanan yang disediakan oleh restoran atau rumah makan yang peredarannya tidak melebihi batas tertentu yang ditetapkan dengan peraturan daerah, misalnya saja tidak melebihi Rp. 30.000.000,00 per tahun.

\section{Subjek Pajak Restoran dan Wajib Pajak Restoran}

Pajak restoran yang menjadi subjek pajak adalah orang pribadi atau badan yang melakukan pembayaran kepada restoran.Secara sederhana yang menjadi subjek pajak adalah konsumen yang menikmati dan membayar pelayanan yang diberikan oleh pengusaha restoran. Sementara itu, yang menjadi wajib pajak adalah pengusaha restoran, yaitu orang pribadi atau badan dalam bentuk apa pun yang dalam lingkungan perusahaan atau pekerjaannya melakukan usaha di bidang rumah makan. Subjek pajak dan wajib pajak pada pajak restoran tidak sama. Konsumen yang menikmati pelayanan restoran merupakan subjek pajak yang membayar (menanggung) pajak sedangkan pengusaha restoran bertindak sebagai wajib pajak yang diberi kewenangan untuk memungut pajak dari konsumen (subjek pajak).

Wajib pajak dapat diwakili oleh pihak tertentu yang diperkenankan oleh Undang-Undang dan peraturan daerah tentang pajak restoran dalam menjalankan kewajiban perpajakannya. Wakil wajib pajak bertanggungjawab secara pribadi dan atau secara tanggung renteng atas pembayaran pajak terutang. Selain itu, wajib pajak dapat menunjuk seorang kuasa dengan surat kuasa khusus untuk menjalankan hak dan memenuhi kewajiban perpajakannya.

\section{METODE PENELITIAN}

\section{Jenis Penelitian}

Jenis penelian ini adalah penelitian deskriptif yaitu untuk memberikan gambaran yang sistematis dan akurat diperoleh dengan mengumpulkan, mengklasifikasikan data sehingga akan memberikan hasil yang konkrit pada permasalahan dan kemudian dilaksanakan analisis sehingga dapat ditarik kesimpulan.

\section{Metode Pengumpulan Data}

Jenis data yang digunakan dalam penelitian ini adalah data kuantitatif berupa data pajak Restoran di Dinas Pengelola Keuangan, Aset dan Pendapatan Daerah Kabupaten Minahasa

Sumber data yang digunakan dalam penelitian ini adalah data sekunder yaitu data yang berasal dari Dinas Pengelola Keuangan, Aset dan Pendapatan Daerah Kabupaten Minahasa.

Data yang dibutuhkan dalam penelitian ini dikumpulkan melalui

1. Penelitian Kepustakaan 
Pengumpulan data dilakukan dengan mempelajari dan membaca buku-buku dari perpustakaan serta data lain yang mendukung dalam proses pembahasan masalah tersebut.

\section{Penelitian Lapangan}

Penelitian ini dilakukan melalui peninjauan langsung ke Dinas Pengelola Keuangan, Aset dan Pendapatan Daerah Kabupaten Minahasa guna memperoleh data yang dibutuhkan dengan cara:

a. Dokumentasi

Mengumpulkan dokumen yang berkaitan dengan masalah yang akan dibahas seperti laporan hasil penerimaan pajak daerah selama tahun 2008-2012 serta kebijakan-kebijakan yang dikeluarkan.

\section{b. $\quad$ Inquires of the client}

Metode penelitian ini dilakukan guna memperoleh informasi mengenai latar belakang dari objek penelitian seperti struktur organisasi, sejarah dari objek yang akan diteliti serta informasi lain yang berhubungan dengan penelitian.

c. Wawancara

Pengumpulan data ini dilakukan dengan melakukan tanya jawab baik dengan pimpinan maupun dengan pegawai yang berada di Dinas Pengelola Keuangan, Aset dan Pendapatan Daerah Kabupaten Minahasa di bidang pajak daerah maupun di bidang perencanaan, pengendalian operasional guna memperoleh informasi yang lebih jelas mengenai masalah yang akan dibahas didalam penelitian.

\section{Definisi Operasional dan Pengukuran variabel}

1. Pajak Restoran adalah pajak atas pelayanan restoran. Pemugutan Pajak Restoran di Indonesia saat ini didasarkan pada Undang-Undang Nomor 34 Tahun 2000 yang merupakan peubahan atas Undang-Undang Nomor 18 Tahun 1997 tentang Pajak Daerah dan Retribusi Daerah dan Peraturan Pemerintah No. 65 Tahun 2001 tentang Pajak Daerah.

2. $\quad$ PAD adalah pendapatan yang diperoleh daerah yang dipungut berdasarkan peraturan daerah sesuai dengan peraturan perundang-undangan yang bersumber dari hasil pajak daerah, hasil retribusi daerah, hasil pengelolaan kekayaan daerah yang dipisahkan, dan lain-lain

\section{Metode Analisis}

Metode analisis yang digunakan dalam penelitian ini adalah analisis deskripsi. yaitu untuk dapat menggambarkan serta menganalisis hasil dari penelitian yang telah dilakukan oleh peneliti. Metode penelitian digunakan peneliti untuk dapat menggambarkan pelaksanaan pemungutan Pajak Restoran Dinas Pengelola Keuangan, Aset dan Pendapatan Daerah Kabupaten Minahasa.h.

Untuk mengetahui kontribusi pajak restoran terhadap pendapatan asali daerah menggunakan rumus berikut:

Kontribusi Pajak Restoran $=\quad \begin{aligned} & \text { Total Penerimaan PAD } \\ & \text { X } 100\end{aligned}$

(Sumber : Indrakusuma, 2011) 
Dengan analisis ini kita akan mendapatkan seberapa besar kontribusi Pajak Restoran terhadap Pendapatan Asli Daerah (PAD) di Kabupaten Minahasa. Dengan membandingkan hasil analisis tersebut dari tahun ke tahun selama lima tahun, sehingga dapat diketahui seberapa besar kontribusi pajak hotel terhadap Pendapatan Asli Daerah Kabupaten Minahasa

\section{HASIL PENELITIAN DAN PEMBAHASAN}

Cara pemungutan pajak hotel berdasarkan salah satu peraturan daerah kota, yang mengatur tentang pajak hotel yaitu tidak diborongkan. Artinya, seluruh kegiatan pemungutan pajak hotel tidak dapat diserahkan pada pihak ketiga dalam proses pemungutan pajak, atau perhimpunan data objek dan subjek pajak. Dan kegiatan yang tidak dapat dikerjasamakan dengan pihak ketiga adalah kegiatan perhitungan besar pajak yang terhutang, pengawasan penyetoran dan penagihan pajak.

Biaya pemungutan adalah biaya yang diberikan kepada aparat pemungutan pelaksanaan pemungutan dan aparat penunjang dalam rangka kegiatan pemungutan. Alokasi pemungutan pajak hotel ditetapkan dengan keputusan walikota dalam rangka pelaksanaan kegiatan pemungutan dan pengelolaan pajak hotel. Diberikan biaya pemungutan sebesar lima persen $(5 \%)$ dari hasil penerimaan pajak yang telah disetorkan ke kas daerah.

Pemungutan pajak harus dilaksanakan secara adil yang berarti bahwa pemungutan pajak harus dilakukan dengan mengatur hak dan kewajiban para wajib pajak, pajak diberlakukan bagi setiap warga negara yang memenuhi syarat sebagai wajib pajak, serta adanya sanksi atas pelanggaran pajak diberlakukan secara umum sesuai dengan berat ringannya pelanggaran.Selain syarat keadilan dalam pemungutan pajak,

Pemungutan pajak harus diusahakan sedemikian rupa agar tidak mengganggu kondisi perekonomian, pemungutan pajak harus efisien dan sistem pemungutan pajak harus dilakukan dengan sederhana. Jika pemungutan pajak dilakukan tanpa mengabaikan syarat-syarat pemungutan tersebut di atas maka dapat terjadi kemungkinan adanya berbagai hambatan dalam pemungutan pajak

Prosedur Pelaksanaan Pemungutan Pajak Restoran di Kabupaten Minahasa, harus melalui beberapa tahapan atara lain:

a. Pendaftaran

1. Menyiapkan formulir pendaftaran

2. Menyerahkan Formulir Pendaftaran

3. Menerima dan memeriksa kelengkapan Formulir

b. Pandataan

1. Menyerahkan Formulir Pendapataan (SPTPD)

2. Menerima dan Memeriksa Kelengkapan Pendataan (SPTPD)

3. Mencatat Data Pajak Daerah

c. Penetapan, menerbitkan :

1. Surat Keterangan Pajak Daerah (SKPD)

2. Surat Ketetapan Pajak Daerah Nihil (SKPDN)

3. Surat Ketetapan Pajak Daerah Kurang Bayar (SKPDKB)

4. Surat Ketetapan Pajak Daerah Kurang Bayar Tambahan (SKPDKBT)

5. Surat Tagihan Pajak Daerah (STPD)

6. Surat Ketetapan Pajak Daerah Lebih Bayar (SKPDLB)

d. Penyetoran

1. Kegiatan penyetoran melalui Bendaharawan Khusus Penerima (BKP)

2. Kegiatan penyetoran melalui Kas Daerah

e. Angsuran dan Penundaan Pembayaran

1. Angsuran Pembayaran

2. Kegiatan Penundaan Pembayaran

f. Pembukuan dan Pelaporan.

1. Pembukuan Penetapan.

2. Pembukuan Penerimaan. 
3. Pelaporan.

g. Keberatan dan Banding

1. Penyelesaian Keberatan.

2. Banding.

h. Penagihan, menerbitkan :

1. Penagihan dengan Surat Teguran.

2. Penagihan dengan Surat Paksa.

3. Penagihan dengan Surat Perintah melaksanakan Penyitaan.

i. Kegiatan Pembetulan, Pembatalan, Pengurangan, Ketetapan dan Penghapusan atau Pengurangan Sanksi Administrasi.

j. $\quad$ Pengembalian Kelebihan Pembayaran.

Kontribusi pajak restoran terhadap pendapatan asali daerah menggunakan rumus berikut:

Kontribusi Pajak Restoran

Total Peneriman Pajak Restoran

Total Penerimaan PAD X 100

Tabel 1. Kontribusi Pajak Restoran Terhadap Pendapatan Asli Daerah Berdasarkan Kabupaten Minahsas Tahun 2008-2012

\begin{tabular}{|c|c|c|c|c|}
\hline No & Tahun & jak Restoran (Rp) & PAD (Rp) & Kontribusi (\%) \\
\hline 1 & 2008 & 1.514 .486 .843 & 15.971 .449 .427 & 9.48 \\
\hline 2 & 2009 & 1.438 .685 .981 & 18.625 .544 .526 & 7.72 \\
\hline 3 & 2010 & 1.652 .482 .402 & 24.660 .933 .541 & 6.70 \\
\hline 4 & 2011 & 1.075 .395 .479 & 23.809 .053 .306 & 4.52 \\
\hline 5 & 2012 & 1.087 .251 .480 & 22.477 .366 .444 & 4.84 \\
\hline
\end{tabular}

Sumber : Dinas Pengelolahan Aset dan Pendapatan Kabupaten Minahasa,

Hasil Tabel 1 dapat dilihat Kontribusi Pajak Restoran Terhadap Pendapatan Asli Daerah Minahasa Tahun Anggaran 2008 sampai dengan 2012 adalah sebagai berikut :

1. Pada tahun anggaran 2008 kontribusi pajak restoran sebesar $9.48 \%$. Hal ini dianggap stabil.

2. Pada tahun anggaran 2009 kontribusi pajak restoran mengalami sedikit penurunan dari tahun 2008 sebesar 7.72\%. Dikarenakan Wajib Pajak yang menunggak pembayaran pajaknya itu sendiri.

3. Pada tahun anggaran 2010 kontribusi pajak restoran terhadap pendapatan asli daerah mengalami penurunan yang tidak terlalu signifikan dari tahun 2010 sebesar $6.70 \%$.

4. Pada tahun anggaran 2011 kontribusi penerimaan pajak restoran terhadap pendapatan asli daerah lebih kecil dari tahun 2010 menurun sangat signifikan menjadi 4.54\%. Ini karena kurang tegasnya petugas pemungut pajak dalam memungut kepada Wajib Pajak dan kemungkinan ada penutupan restoran karena tidak membayar pajak.

5. Pada tahun anggaran 2012 penerimaan pajak restoran terhadap pendapatan asli daerah mengalami peningkatan sedikit dari tahun 2012 sebesar $4.84 \%$.

\section{PENUTUP}

\section{Kesimpulan}

1. Pelaksanaan pemungutan pajak telah berjalan baik dan mudah untuk dipahami serta bukti potong pembayaran dapat diberikan kepada wajib pajak. Tetapi setiap terjadi perubahan peraturan, petugas pemungut pajak dalam hal ini pemerintah daerah terlambat dalam mensosialisaikannya kepada wajib pajak. Sehingga masih ada wajib pajak belum membayarkan pajaknya. 
2. Kontribusi pajak restoran terhadap pendapatan asli daerah dapat dikatakan cukup baik walaupun setiap tahunnya mengalami penurunan. Walaupun demikian secara keseluruhan sudah mencapai target yang sudah ditetapkan.

\section{Saran}

1. Dalam rangka terwujudnya sistem administrasi dan prosedur pemungutan yang baik pada Dinas Pendapatan dan Pengelolaan Keuangan maka di utamakan melakukan pelayanan yang baik lagi dari pemerintah daerah kepada masyarakat terutama kepada Wajib Pajak dalam mensosialisasikan perubahan peraturan yang dapat mudah untuk di akses dengan modern koputerisasi agar wajib pajak dapat memenuhi kewajibannya dengan mudah, dimanapun dan kapanpun serta memperbaiki seluruh proses pengawasan terkait proses pemungutan.

2. Agar tidak dilakukan penutupan restoran sebaiknya pemerintah daerah memberikan surat teguran atau sanksi tegas kepada wajib pajak untuk segera membayar kewajiban perpajaknnya tepat waktu.

3. Untuk lebih mengoptimalkan penerimaan pajak restoran pada pencapaian target, diupayakan melaksanakan pengawasan untuk meningkatkan lagi kinerja petugas sehingga pencapaian kontribusinya semakin meningkat, mengingat banyaknya perkembangan bisnis restoran di Kabuapten Minahasa yang dapat meningkatkan pendapatan asli daerah.

\section{DAFTAR PUSTAKA}

Indrakusuma, Arieyani 2011. Potensi Penerimaan Dan Efektifitas Pajak Penerangan Jalan di Kota Semarang. Skripsi S1 Fakultas Ekonomi Universitas Diponegoro Semarang. (http://eprints.undip.id, diakses 2 November 2013).

Mardiasmo, 2009, Perpajakan, Edisi Revisi, ANDI, Jogjakarta.

Republik Indonesia, Undang-Undang Nomor 18 Tahun 1997 Tentang Pajak Hotel dan Restoran

Republik Indonesia, Undang-Undang Nomor 34 Tahun 2000. tentang Perubahan Atas undang-Undang Republik Indonesia Nomor 18 Tahun 1997 tentang Pajak Daerah dan Retribusi Daerah

Republik Indonesia, Undang-Undang No. 33 Tahun 2004 Tentang Perimbangan Keuangan Antara Pusat dan Pemerintah Daerah

Republik Indonesia, Undang-Undang No. 34 Tahun 2004 Tentang Pajak dan Retribusi Daerah

Republik Indonesia, Undang-Undang No. 28 Tahun 2009. Tentang Pajak dan Retribusi Daerah

Republik Indonesia, Peraturan Pemerintah No. 65 Tahun 2001 tentang Pajak Daerah

Siahaan Marihot, P, 2008, Pajak Daerah dan Retribusi Daerah, Edisi 1, PT. Raja Grafindo Persada,Jakarta. 